NBER WORKING PAPER SERIES

THE LABOR MARKET EFFECTS OF

INTRODUCING NATIONAL HEALTH

INSURANCE: EVIDENCE FROM CANADA

Jonathan Gruber

Maria Hanratty

Working Paper No. 4589

NATIONAL BUREAU OF ECONOMIC RESEARCH

1050 Massachusetts Avenue

Cambridge, MA 02138

December, 1993

This paper is part of NBER's research programs in Health Care, Labor Studies and Public Economics. Any opinions expressed are those of the authors and not those of the National Bureau of Economic Research. 


\title{
THE LABOR MARKET EFFECTS OF \\ INTRODUCING NATIONAL HEALTH \\ INSURANCE: EVIDENCE FROM CANADA
}

\begin{abstract}
$\underline{\text { ABSTRACT }}$
While National Health Insurance (NHI) plans in the U.S. are often opposed on the basis of their potential disemployment effects, there is no existing evidence on the effects of NHI on employment. We provide such evidence by examining the employment consequences of NHI in Canada, using the fact that NHI was introduced on a staggered basis across the Canadian provinces. We examine monthly data on employment, wages, and hours across 8 industries and 10 provinces over the $1961-1975$ period. We find that employment actually rose after the introduction of NHI; wages increased as well, while average hours were unchanged.
\end{abstract}

Jonathan Gruber Department of Economics Massachusetts Institute of Technology Cambridge, MA 02139 and NBER

\author{
Maria Hanratty \\ Department of Economics \\ Princeton University \\ Princeton, NJ 08544 \\ and NBER
}


Heaith insurance reform in the U.S. appears inevitable. The rapid growth of medical costs, which have tripled as a share of GNP since 1950 (Newhouse, 1992), and the large fraction of the population without insurance has caused policy makers to consider substantial changes our health care system. One option which has received considerable support is national health insurance (NHI), which offers publicly financed health insurance to al citizens. Such a system is in place in Canada, and it has been widely commended as one which provides universal health insurance coverage while spending only $75 \%$ as much, per capita, as the U.S. on health care (Government Accounting Office. 1991). However, a major objection to this approach is that it would increase government taxation, with resultant deadweight loss and reduced economic activity. Indeed, the specter of large scale disemployment has been a major impediment to the serious consideration of this program at a policy level.

Despite concern over the disemployment effects of NHI, we currently have little empirical evidence on the effects of NHI on employment. Most analyses of the impact of NHI consider only the effects of increasing taxes to finance the program (Browning and Johnson, 1980); not surprisingly, such analyses produce estimates of sizeable disemployment effects. However, the introduction of national health insurance differs from the introduction of a new tax in at least two ways. First, the program is replacing a primarily employer-provided benefit with a publicly provided one, which can have additional effects on both the composition and the level of employment. Recent research has highlighted the key differences between pure tax policies, and policies which interact with the provision of employee benefits; see Summers (1989) for a general discussion, and Gruber and Krueger (1990), Gruber (1993), Viscusi and Moore (1987), or Moore and Viscusi (1990) for empirical results. Second, increased health insurance coverage may have important implications for the functioning of the labor market, such as through increases in job mobility or the health of the 
workforce.

We therefore propose an alternative to studies which rely on preexisting evidence on tax incidence to impute the effects of national health insurance on the labor market: an examination of the transition to NHI in Canada. This approach has two distinct advantages. First, since Canada is similar to the U.S. in both demographic and economic structure, its experience may be representative of what might happen if the U.S. moved to a public insurance program. Second, the Canadian provinces implemented $\mathrm{NHI}$ at different points in time; national health insurance was first introduced in Saskatchewan in 1962, then in the remainder of the provinces in the 1968-1971 period. Thus, we can identify its effect by comparing provinces which have implemented NHI with those which have not implemented $\mathrm{NHI}$ at a point in time. In this way, the Canadian experience serves as a "natural experiment" from which lessons for the U.S. can be drawn.

To estimate the impact of NHI, we use monthly data on employment, wages, and hours of work for the years 1961-1975 for 8 industries in 10 Canadian provinces. We first model these labor market variables as a function of whether NHI was in place in a given province/industry/month/year. We then explore a variety of dynamic specifications, and allow the impact of NHI to vary across provinces and industries.

Contrary to expectations, we find that NHI did not cause a significant fall in employment in Canada. In fact, implementation of NHI was associated with a rise in both employment and the nominal wage rate. This conclusion is robust to a variety of specifications which control for the potential endogeneity of the timing of implementation of NHI. Our evidence further suggests that the increase in employment reflects "permanent" increases, rather than short run adjustments in employment and wages; and that wages appear to adjust more rapidly than employment to implementation of NHI. 
Finally, our analysis suggests that NHI is associated with larger decreases in employment in provinces which use general revenues (rather than lump-sum premiums) to finance NHI. We find some evidence that $\mathrm{NHI}$ is associated with a relative increase in employment in sectors with high initial private health insurance coverage rates, although this result is not very robust.

\section{BACKGROUND ON CANADA AND NHI}

NHI was implemented in two steps: introduction of public insurance for hospital expenses in the 1950s, and introduction of public insurance for medical services in the 1960s. In both cases, a few provinces initiated programs which served as a model for federal legislation. The federal government then passed legislation which promised federal matching funding to approved provincial plans. Finally, the remaining provinces added public plans which conformed to federal guidelines.

The implementation of public insurance for hospital expenses in Canada spanned the period from 1947 to 1961 . The federal government passed legislation supporting provincial hospital insurance programs in 1957. By January, 1961 all provinces had implemented a hospital insurance program. Because our data are not available prior to 1961, our paper will not focus on the impact of extending hospital insurance coverage.

The implementation of public insurance for medical expenses began in Saskatchewan in 1962. precipitating a prolonged doctors strike (Taylor, 1987). Alberta, Ontario, and British Columbia then introduced voluntary public insurance programs which offered subsidized rates to the poor. On July 1,1968 , the federal government introduced legistation which promised $50 \%$ federal funding to qualified provincial programs. Both Saskatchewan and BC automatically qualified at passage of federal legislation. Five other provinces enrolled during 1969, followed by Quebec and Prince Edwards Island in 1970, and New Brunswick in January, 1971. These dates of enrollment are 
presented in Table l.

While provincial medical insurance programs offered similar services and conditions for enrollment, their financing mechanisms differed substantially. Half of the provinces financed part of provincial costs with premiums assessed on individuals; the remaining provinces (as well as the federal government) relied exclusively on general or earmarked tax revenues. These premiums approximated "lump sum" taxes for moderate and upper income individuals, since the total contribution did not vary with employment or hours of work (they only varied between individual and family coverage). For low-income individuals, premium contributions were subsidized; but these individuals typically received health insurance subsidies prior to NHI in premium financed provinces (Aberta, British Columbia, Ontario, Saskatchewan), so that there was no net change in their incentives for labor supply.

In Table 1, we present estimates of the percent of the provincial share of program contributions funded by premiums for the first year of each program, and for the last year for which we have data (1975). The data are from Provincial Government Finances (various years). Estimates prior to 1970 are based on medical expenses only. After 1970, we can not separate hospital from other medical expenses. Thus, we use trends in hospital and medical spending to adjust the 1969 figure forward through time. As shown, even the premium provinces relied to some extent on general revenues, and by 1975 Manitoba and Saskatchewan had removed premium financing altogether.

At the time of implementation of NHI, the scope and sources of insurance coverage in Canada was quite similar to that in the U.S. today. Most of the Canadian population was covered by private health insurance, and thas insurance was provided primarily through their employers. Using estimates based on private insurance enrollments, Berry (1965) reports that $53 \%$ of the 
population had medical insurance in 1961, while Shillington (1972) reports that $70 \%$ had private insurance in 1966 (this figure excludes Saskatchewan, which already had a public insurance program at this point). In the U.S. in 1991, 70\% of the nonelderly population was covered by private insurance (based on authors' tabulations from the March 1992 Current Population Survey).

However, the structure of the Canadian insurance market differed in two key ways from the current structure of the U.S. market. The first is the extent of "experience rating"; that is, the extent to which a firm's insurance costs reflects its own claims experience. There were two types of private medical insurance coverage in Canada in the mid-1960s. The "Medical Prepayment Plans", run by the provincial medical associations, were community rated; premiums were not based on a group's own experience, but on the experience of all groups (or some subset of groups) using that insurer. On the other hand, Commercial insurance plans were experience rated. These two types of insurers each occupied about one-half of the market in the mid 1960s (Shillington, 1972). In contrast, in the U.S. in 1991, there was much less use of community rating. Commercial insurance companies, which have $60 \%$ of the market for traditional private insurance (Health Insurance Association of America, 1991), fully experience rate their customers. Blue Cross/Blue Shield plans, which control the remaining $40 \%$ of the market, only community rate the smallest firms in most states (Congressional Research Service, 1988).

The second major difference is the cost of health insurance. Several sources of data for this era suggest that the cost of private medical insurance was relatively modest, ranging from $3-4 \%$ of average wage levels. The Royal Commission on Health Services (RCHS, 1965) reported that the cost of a medical insurance plan in Alberta was $\$ 159$ for a family, or $3.8 \%$ of the average wage in that province in 1963 . In Manitoba, family coverage cost only $\$ 138$ per year, which was $3.5 \%$ of the average wage. And Berry (1965) reports costs from a large insurance company in Manitoba of 
$\$ 108$ per year for a family in 1961, which was $2.9 . \%$ of wages in that province/year. In the US in 1989, a typical employer-provided family insurance policy cost $\$ 262$ per month (based on unpublished Health Insurance Association of America data), or approximately $16.6 \%$ of average wages as compared to the $3-4 \%$ estimate for Canada. This comparison overstates the difference in costs, since the U.S. estimate includes both medical and hospital insurance costs, while the Canadian figure covers only medical insurance. However, since Canada's medical insurance costs in this period represented about one-half of total expenses, U.S. insurance costs as a fraction of wages are at least twice as large as they were in Canada in the 1960s.

Finally, there are important differences in labor market institutions in boch countries. In Canada in 1965, 39\% of workers in firms with 15 or more employees were in firms where the majority of workers were covered by collective bargaining agreements. In contrast, in the U.S. in 1991, 18\% of all wage and salary workers were represented by unions (US Dept of Commerce, 1992). As Summers, Gruber, and Vergara (1993) highlight, differing labor market institutions may inhibit comparisons of the effects of public policies across countries.

\section{THEORY OF NHI FINANCING}

In this section, we present a heuristic discussion of the labor market effects of NHI. For this analysis, we ignore changes in the demand for labor induced by changes in product demand, and focus oniy on changes in the firm's total labor costs. While this omission could be critical for understanding changes in the health care sector, our labor force data excludes health care workers, and does not permit us to identify the effect of NHI on the health care sector. We also ignore any effects from increasing government employment and decreasing private sector employment as the administration of health insurance was moved to the public sector. 
We assume that NHI is financed by one of two methods: lump sum premiums or general revenue financing. We assume that all general revenues are financed through proportional income taxes, and that afl premium and income taxes are levied on the worker and not on the firm.. This assumption is not unrealistic: nearly three-quarters of provincial general tax revenue in 1967 was raised by taxes on income or sales (Canadian Tax Foundation, 1967), although the income taxes were steeply progressive.

Consider first the case where no firms offer health insurance. In this case, NHI will have no impact on the firm's labor costs, and the demand for labor will be unaffected. There may, however, be an income effect of the premium levy on labor supply. The net change in income for the worker is the difference between their value of the health insurance which they are being provided and the premium cost which they must pay. If health insurance is valued less than this premium, then income will be falling, and labor supply (and thereby employment) will increase.

In contrast, a program financed by taxing workers should cause a decrease in labor supply (assuming sutstitution effects dominate income effects), since it decreases the value of work relative to leisure. In this case, NHI will lead to a decrease in employment and an increase in wages. This is the standard result from tax incidence analysis, as used in Browning and Johnson's (1980) analysis of NHI.

We next consider the role of employer provided health insurance before the introduction of NHI. The theory of compensating differentials (Rosen, 1986) suggests that the firm will provide health insurance until the marginal cost to the firm is set equal to the marginal worker's valuation of that insurance. Under a particular form of this model, with equal costs across employers, a continuous distribution of health insurance policies by generosity, a continuous distribution of worker preferences for health insurance, perfect information on worker preferences, and the ability to set 
worker-specific compensation packages, workers will each be paid their marginal product minus their valuation of health insurance. In that case, the introduction of NHI (ignoring for the moment financing considerations) will have no effect on employment. Each workers wage will rise by the amount of their valuation of health insurance, and the employer's total compensation costs will be unchanged.

If these assumptions are violated, however, NHI may have further employment effects through supply side responses. One of these assumptions that is violated in reality is that the costs of health insurance are equal for all employers. Discontinuities in firm costs may result, for example, from differences in the loading factors on insurance policies across firms of different sizes; alternatively, a system of experience rating may impose discrete jumps in health insurance costs across firms in response to underlying risk. In the U.S. today, the loading factor on group health insurance policies for small firms is almost $40 \%$ higher than that for large firms (Congressional Research Service, 1988). Berry (1965) documents wide variation in loading factors between group and individual insurance (a proxy for the cost to the small firm) even for Canada in the 1960s. Furthermore, in our experience rated system many firms have been "redlined" and cannot purchase insurance at any price; this imposes an infinite discontinuity in the price of insurance to the firm. It is not clear whether this sort of unavailability was a problem in Canada in the 1960s.

With discontinuities across firms in the cost of health insurance, the low cost firms will be able to both offer insurance and pay low wages, by attracting those workers who most value that insurance. Other firms will have to have a higher total marginal product to keep the marginal worker indifferent between working for them and for the firm that offers health insurance.

In this type of siruation, NHI can have major supply side consequences on the labor market. When NHI is introduced, it causes a relative decline in the real compensation in the highly-insured 
sector, and cause a shift in employment towards the sector with low insurance coverage. That is, the low cost firms loses the advantage that they incurted from the cheap availability of employer provided health insurance; NHI taxes away that advantage by making insurance available to all, equally cheaply. If these high cost/low insurance sectors are labor intensive, it could cause increases in the overall level of employment.

There are at least two other complications to the employment predictions of the basic tax incidence model. First, in the case where firms offer health insurance, labor market rigidities can cause a rise in employment. That is, if firms are unable to adjust wages upwards when NHI was put in place, then their total labor costs would drop, leading to a rise in labor demanded. Such rigidities could arise from collectively bargained contracts, given the high rate of unionization in Canada.

Second, we do not consider the effects of NHI on the productivity and health of the workforce. Recent research (Madrian, 1993) has uncovered strong evidence for insurance-induced immobilities in the labor market, or "job lock". While the welfare implications of job lock are unclear ex ante, it is at least possible that increasing mobility can raise the productivity of the workforce by increasing the efficiency of job matches. Similarly, investments in health care may improve the health and productivity of the work force; since the gains are to general productivity, it may not have been in the interest of individual firms ex ante to invest in health insurance to capture these gains. Hanratry (1992) finds strong evidence of the effects of NHI on at least one indicator of health outcomes, infant mortality. These productivity increases may lead to a long run rise in employment with the implementation of $\mathrm{NHI}$. 


\section{DATA AND SPECIFICATION}

\subsection{The Dasa}

Our data for this analysis contains information on wages, employment and hours for eight industries in ten provinces for each month from 1961 to 1975 . The eight industries are forestry. mining, manufacturing, transportation, construction, trade, FIRE, and some service industries (hotel, restaurants, laundry and dry cleaning, recreation and business services). Health care services are nef included in this survey. Data are missing for forestry, mining, construction, and services for some provinces, so that our total sample has 12,240 observations. Table II provides a description along with means and standard deviations of each variable.

We have drawn our information on employment, wages and hours from published data based on Statistics Canada's Monthly Survey of Employment and Weekly Payrolls. Prior to 1966, this was a survey of all Canadian firms which "usually employed" 15 or more workers; stanting in 1966 it includes all firms which have employed 20 or more employees in at least one month during the preceding year. The change in the firm size restriction had little impact on the scope of the survey: aggregate data for Canadian industries by year shows that the average percentage of employees in each industry represented in the survey did not change by more than $3 \%$ from 1964 to 1966 . This incomplete coverage means that our employment results will not account for movements of workers from very small to larger firms or vice versa; however, the high overall coverage of the survey (approximately $75 \%$ of employment) implies that this may not be an important problem.

Our primary labor market outcome measures are total employment and average weekly earnings. Total employment includes all workers on the payroll during the last week of the month; it includes both full and part-time workers. Average weekly earnings includes base wages plus overtime or bonus payments. It includes employee contributions and excludes employer contributions 
to workers compensation, pensions, unemployment insurance or medical insurance plans.

We also have information for a restricted sample of industries (mining, manufacturing, construction) on weekly hours and average hours per week for employees paid by the hour for the years 1965 to 1975 . We impute weekly hours for all salaried employees by assigning them a value of 37.5 hours.

Our basic measure of the effect of introducing NHI is a dummy variable which equals zero prior to the month of implementation of national health insurance in each province and which equals one afterwards. These dates are shown in Table I. For Saskatchewan, we assume that NHI equals 1 from July 1962, the date that this province implemented universal health insurance program (rather than the date it entered the federal program).

We also interact the NHI dummy with a variable, \%Tax; which is equal to one minus the share of provincial contributions to NHI which are financed by premiums. As shown in Table I, there is substantial variation in this variable both across provinces at a point in time, and within provinces over time.

Finally, we interact NHI with HICOV, a measure of the share of the workforce covered by private health plans prior to national health insurance. This measure comes from a survey of working conditions among firms in Canada in 1965. This source has the natural advantage for our analysis that it focuses on employer-provided insurance coverage. In addition, it uses the same sampling frame as our labor market data (firms with 15 employees or more). The main disadvantage of this data source is that it is not very precise: the figures are for the fraction of workers who are in firms where the majority of employees were covered by a health insurance plan.

Unfortunately, the published data from the survey provides information by province and by industry, but not by industry within province. We have therefore imputed rates of insurance 
coverage for each industry by province "cell" in two steps. First, we calculate the "excess" coverage rate in a given province as the actual coverage rate relative to that which would have been expected given the industrial mix of the province and the average rates of insurance coverage (nationwide) across industries. For each industry in each province, we then adjust the nationwide coverage rate for that industry by the "excess" coverage rate for that province.

The only control variables in the model are the log, or change in log, annual GDP by province, and monthly GDP by industry (nationally); the former is from Canada, Dominion Bureau of Statistics (Selected Years), while the latter is from Statistics Canada (1988). In earlier work, we also controlled for population levels and changes; these variables never entered significantly and did not effect the coefficients of interest, so we excluded them from this analysis.

\subsection{The Model}

Our basic regression specification for the employment equations is:

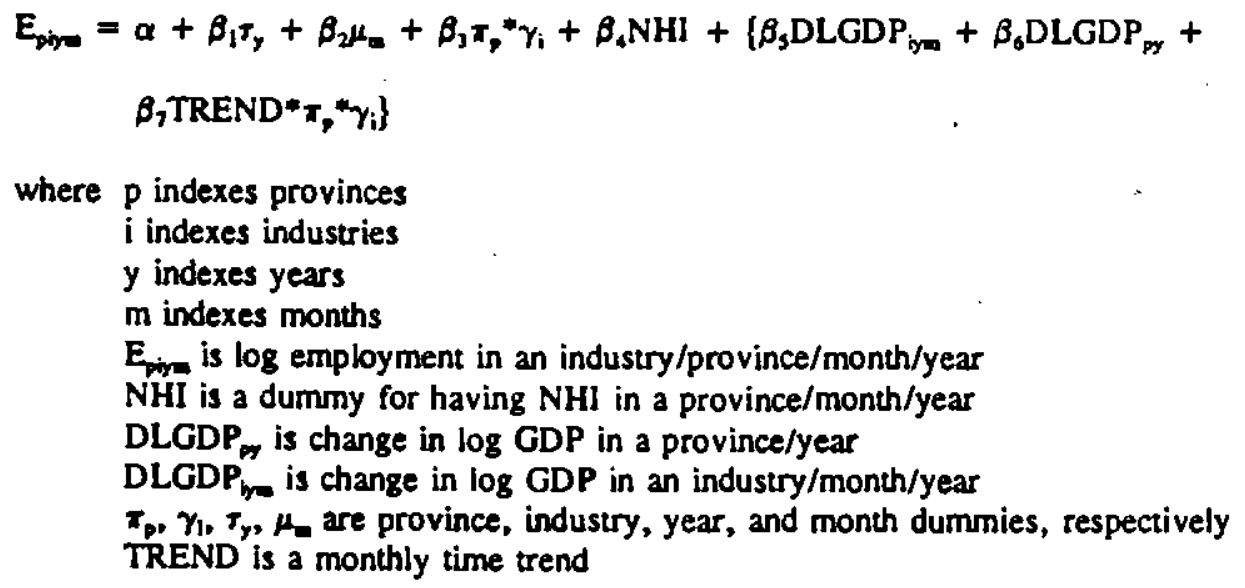

The unit of observation, as described above, is an industry within a province in a given month and year. Our key variable of interest, NHI, varies by province, month, and year. The goal of our regression specification is to control for factors which might be correlated with the passage 
of $\mathrm{NHI}$ and thereby confound our interpretation of $\beta_{4}$. For example, we control for year effects to capture nationwide time series shocks to employment or wages which might be correlated with NHI. We control for month effects to capture cyclicality in the output of these different industries. We include dummies for every industry/province cell in order to pick up any fixed differences across these cells which may be correlated with the likelihood of NHI passage. Thus, we identify the effects of NHI by deviations of log employment from its industry/province cell mean.

This specification may not control for all factors which are associated with the passage of NHI. For example, if NHI is more likely to be implemented in provinces with rapid growth in output and employment, then our estimate of the impact of NHI on employment will be biased upward. To control for this effect, we add two controls for output: the (year to year) change in log annual GDP by province and in log monthly GDP by (national) industry. We control for the change rather than the level of $\log$ GDP, because it is likely that wage and employment deviations from province/industry means are caused by deviations in output from its expected province/industry growth path. These measures are themselves potentially endogenous, since NHI may cause changes in productivity across provinces or industries. Thus, this provides a conservative test of the impact of NHI. In order to measure the growth in GDP, we drop the first year (1961) from our sample in all specifications.

As an alternative approach, we include not only province/industry fixed effects, but province/industry trends as well. That is, following Lalonde, Jacobson, and Sullivan (1993), we include in the basic model a monthly trend, and interact that trend with each province/industry fixed effect. This specification captures the effect of NHI on deviations of employment and wages from their province/industry growth paths, rather than deviations from their average levels. In this specification, we control for the log of output, rather than the growth rate. This is because we want 
15

to retain the consistent interpretation of a control for deviations of GDP from its expected growth path; since we control for the growth path here, the level. of GDP picks up the deviation. The results are not sensitive to the use of GDP changes in this specification.

Finally, in order to further assess the possibility of reverse causality or other spurious correlation, we perform a specification check. We add to specification (1) an additional dummy which is equal to one if NHI will be passed in the next year, and zero otherwise. If NHI is having a causal effect on wages and employment, then this term should have a coefficient of zero. If, instead, the passage of NHI is an endogenous response to other changes in the environment, or is even simply correlated with other changes, then this term will be non-zero.

The province/industry cells which make up our data set are of varying sizes; employment ranges from $\$ 70$ to over 850,000 . This may induce heteroskedasticity in our error terms. In order to correct for this heteroskedasticity in a robust manner, we use the standard errors corrected according to the formula of White (1980).

\section{RESULTS}

\section{J Basic Findings}

Table III presents estimates of the impact of $\mathrm{NHI}$ on log employment and log wages. Surprisingly, there is a significant rise in employment with the passage of NHI; it is associated with a 2\% rise in employment. This may suggest that it is important to extend the basic theory outlined in Part Il. Alternatively, it may simply be an artifact of the fact that provinces with rapid employment growth are more likely to pass NHI. The remainder of the top half of Table III is devoted to assessing this alternative hypothesis.

In the second column, we include the controls for the growth in provincial and industrial 
GDP. Both variables indicate a strong positive correlation between output growth and employment growth. However, the coefficient on NHI increases with the inclusion of these controls, and now indicates that $\mathrm{NHI}$ is associated with a $2.6 \%$ rise in employment.

In the third and fourth columns, we include a lead value of $\mathrm{NHI}$ (NHI next year) to test for the endogeneity of passage of $\mathrm{NHI}$. As shown, both with and without controls for GDP, the coefficient on NHI next year is small and statistically insignificant. The coefficient on NHI remains strong and significant, indicating employment growth in excess of $2 \%$.

The final four columns include province/industry trends; columns (5) and (7) exclude GDP controls, while columns (6) and (8) include them. As shown, adding controls for province/industry trends reduces the estimated magnitude of the impact of NHI to 1.3\%-1.7\%, and NHI remains at least weakly significant in all specifications. As before, controls for GDP are positive and significant, but do not substantially affect the measured impact of NHI. Furthermore, the specification check discussed above once again provides no evidence of reverse causality; the coefficient on NHI next year is always substantively and statistically insignificant.

The bottom panel of Table III examines the effect of NHI on wages, using the same set of specifications discussed above. As shown, NHl is associated with a very strong and significant rise in wages, on the order of $3 \%$ of wages (column 1). This finding is robust to the inclusion of GDP controls (column 2). The lead value of NHI is significant and positive (columns 3 and 4), suggesting potential endogeneity between the passage of NHI and wage growth. However, the contemporaneous effect of NHI is significantly larger than the lead value of $\mathrm{NHI}(4 \%$ vs $2 \%$ ), suggesting that at least part of the impact of NHI is not due to the greater growth rates of provinces which pass NHI.

With the inclusion of province/industry trends (columns 4-8), the impact of NHI decreases in magnitude to $1.5 \%$, although it remains highly significant in all specifications. This specification 
is not sensitive to the inclusion of controls for GDP or for the lead value of NHI. In addition, the coefficient on $\mathrm{NHI}$ next year is not significant, suggesting that there may be no endogeneity between NHI and deviation of wages from urend. This is therefore our preferred estimate for the wage effects.

\subsection{Hours Effects}

One explanation for the positive correlation between $\mathrm{NHI}$ and employment may be that national health insurance caused an increase in part-time employment. Since publicly provided health insurance reduces the fixed costs of employment, it may encourage firms to hire part-time workers. Gruber (1993) finds evidence that mandating employment benefits increases hours and decreases employment. If the reverse of this effect holds true when Canada implements NHI (since employers no longer offer health insurance), then $\mathrm{NHI}$ may increase employment, even while it has no effect on total hours of work.

Table IV tests this hypothesis by estimating the impact of NHI separately on log total weekly hours, log employment, and log average hours per week per worker for the subset of the sample which includes information on hours of work. For each of these variables, the first column uses the model without province/industry trends, and the second column includes these trends; both columns are estimated with GDP controls (the results are not sensitive to their inclusion). Note that this is not a perfect test for the impact of NHI on part-time work, since it mixes together both changes in over-time and changes in part-time employment. If NHI reduced the fixed costs of employment, it might both decrease over-time work and increase part-time work, thus resulting in little aggregate change in average hours per week. Unfortunately, we do not have more detailed measures of the changes in hours of work per week. 
As shown, the positive impact of NHI on employment is not explained by an decrease in average hours per worker. The estimates of the impact of NHI from the log total hours equation are quite similar in magnitude to those in the log employment equation for this subsample, while the estimated impact of NHI on average hours are small and insignificant. This indicates that most of the adjustment occurred through changes in employment rather than through changes in average hours of work per week. This result is similar whether or not province/industry trends are included.

\subsection{Time Partern of Effects}

In Table S, we trace out the time pattern of effects. We include dummies for: NHI implemented 4, 3, 2, and 1 quarter from now, NHI implemented $1,2,3,4,5,6,7$, and 8 quarters ago, and NHI implemented more than 8 quarters ago. This specification allows for a more detailed test of the endogeneity of NHI; it also enables us to discern how rapidly the effect of NHI on employment and wages is realized.

Boch specifications suggest a slow adjustment of employment to NHI: there is little effect in the first two quarters, then a rise of approximately $2 \%$ over the next four quarters, followed by a larger rise from quarters $7-8$ and continuing onwards.

As before, the lead values of NHI are all insignificant in the basic employment equation (column 1). However, with the inclusion of province/industry trends (column 2), the coefficient on $\mathrm{NHI}$ in 1 quarter becomes significant at the $11 \%$ confidence level suggesting some endogeneity in the NHI variable. This effect is still smaller in magnitude than the measured impact of NHI after implementation of the program, however; it is approximately $1 / 2$ of the steady state employment increase. This suggests that all of the measured impact is not due to endogeneity.

The estimates suggest a somewhat faster adjustment to NHI for wages than for employment: 
after NHI is passed, the effects are small for three quarters, then rise to a significant 2.5-3\% level from quarter 4 onwards. We once again see strong evidence of NHI endogeneity in the basic specification (column 3), since all lead values of $\mathrm{NHI}$ are highly significant. After controlling for province/industry trends (column 4), there is still a significant rise in the quarter immediately preceding NHI, although the other lead values are insignificant. The magnitude of this lead term is only about $1 / 3$ of the size of the steady state wage increase.

\subsection{Effect of NHI across Province/Indusiries}

As noted in Part II, we anticipate that the impact of NHI should vary both with the mechanism of financing NHI used in each province, and with the relative cost of private health insurance in each industry/province prior to NHI. Thus, in Table VI, we allow the impact of NHI to vary across province/industry, by adding two interaction variables: $\mathrm{NHI}^{*} \% \mathrm{Tax}$ is an interaction of $\mathrm{NHI}$ with the percent of provincial NHI expenditures financed by general revenue taxation; while $\mathrm{NHI}{ }^{*} \mathrm{HICOV}$ is an interaction with the share of private insurance coverage in each province/industry prior to NHI. To the extent that high cost sectors had lower rates of private insurance coverage prior to NHI, this measure is a proxy for variations in health insurance costs.

In Table VI, we present estimates for both employment and wages, using the same specifications as in previous tables. Since information on health insurance coverage is not available for the forestry or construction industries; this data contain a more limited sample of observations $(n=9072)$.

In the employment equations, NHI*\% Tax is negative and highly significant in the basic specifications (columns 1-2); when province/industry trends are added, it declines in magnitude but remains significant. The estimates from the base specification suggest that shifting from a $100 \%$ 
premium-financed to a $100 \%$ general revenue financed program would decrease employment by $20 \%$, while the specification with trends suggests a decline of $4-5 \%$, which is more reasonable. The results therefore imply that the finding of an overall rise in employment masks substantial heterogeneity by financing source; as predicted by tax incidence analyses, employment does fall where $\mathrm{NHI}$ is financed from general revenues.

The measured effect of $\mathrm{NHI}^{*} \mathrm{HICOV}$ on employment is less robust to the inclusion of trend variables. In the baseline specification, $\mathrm{NHI}^{*} \mathrm{HICOV}$ is negative and highly significant, suggesting a substantial shift in employment from high coverage to low coverage industries: for example, it suggest an employment decline of $7 \%$ for every $10 \%$ increase in initial private insurance coverage. Once province/industry trends are included, this variable becomes positive and insignificant, suggesting little change in employment across sectors.

The estimates of the impact of both $\mathrm{NHI}^{*}$ \% Tax and $\mathrm{NHI}^{*} \mathrm{HICOV}$ on wages are highly sensitive to the inclusion of trend variables. In the baseline specification, $\mathrm{NHI}$ \% $\mathrm{Tax}$ is positive and weakly significant, consistent with the hypothesized decrease in labor supply with general revenue finaricing. Similarly, $\mathrm{NHI}^{*} \mathrm{HICOV}$ is positive and significant, as one would expect if relative labor supply were decreasing in sectors with high initial private insurance coverage rates. However, both of these variables become negative and highly significant with the inclusion of trend variables. Thus, it is not possible from these tables to conclusively determine the impact of these variables on wages.

\section{DISCUSSION AND CONCLUSIONS}

While there is a vigorous debate over the merits of national health insurance for access to health services and the cost of medical care, there has been little attention paid to the consequences of financing NHI. This is unfortunate, because misgivings about the labor market impact of NHI 
may prove to be a major impediment to its implementation. These misgivings, moreover, are based on the simple application of tax incidence models to the complicated question of what happens when a largely privately provided benefit is replaced with a publicly provided one. In this paper, we have suggested an alternative approach: an examination of the "natural experiment" presented by Canada's transition to $\mathrm{NHI}$.

Contrary to expectations, we find no evidence that implementation of NHI resulted in a decrease in employment. In fact, we find that both employment and wages increased with implementation of NHI. This result is robust to a number of specifications which control for the potential endogeneity of $\mathrm{NHI}$, and it does not appear to be an artifact of a change in the average number of hours per employee.

In Part II, we suggested several hypotheses which would be consistent with this paradoxical result. While we are not able to structurally test these competing hypotheses, our findings do offer us some ability to distinguish between them. The fact that the employment adjustment appears to have occurred with a substantial lag casts some doubts on explanations based on the income effects of the premiums levied on workers. Furthermore, the faster rate of adjustment of wages than employment, along with the effects on employment in the long run only, suggests that our finding is not due to labor market rigidities which prevent nominal wages from adjusting upwards after passage of $\mathrm{NHI}$.

A further possibility is that NHI caused an employment shift to high-cost, labor-intensive sectors, such as the service industry. Our evidence on this point is mixed: while we find some evidence of a relative increase in employment in sectors with initially low rates of private insurance coverage, this result is sensitive to the inclusion of trend controls. The hypothesis which is most consistent with our findings is that NHI caused a systematic increase in labor demand across all 
sectors. This may have arisen due to increases in labor productivity which followed increased job mobility or improvements in the health of the labor force. Distinguishing between these remaining hypotheses remains a task for future research.

Prior to implementation of NHI, Canada was similar to the U.S. in its reliance on employerprovided health insurance, and in its mixture of commercial experience-rated and non-profit community rated plans. Thus, it is plausible that our results can generalize to the U.S. case. However, several factors may cause the impact of NHI to differ in the U.S. First, the cost of private hospital and medical insurance now represents a much larger share of U.S. wages than did medical insurance in Canada. If the necessary revenues are raised by distortionary general revenue taxes, the U.S. may well experience a decline in employment. On the other hand, the U.S. insurance market is more highly segmented than was the market in Canada, with many firms unable to purchase insurance at all. This may lead to larger sectoral shifts when NHI is put in place; if these shifts are into labor intensive sectors, the increase in employment will be larger than in Canada.

We are grateful to Josh Angrist, Janet Currie, Richard Freeman, Jim Poterba, George Tauchen, and two referees for helpful comments; to Matt Barmack, Sharieff Mansour, Cory Rattelman and Michael Cooper for research assistance; and to the Canadian Employment Research Forum for financial support. 
References

Berry, Charles H. (1965), "Voluntary Medical Insurance and Prepayment," Ottawa: Queen's Printer.

Browning, Edgar K., and William R. Johnson. (1980). "Taxation and the Cost of National Health Insurance, "National Health Insurance: What Now, What Later, What Never? Mark V. Pauly, ed.

Canada, Dominion Bureau of Statistics, Labour and Prices Division, Employment Section, Review of Man-Hours and Hourly Eamings, Catalogue 72-202, Selected Years.

Canada, Dominion Bureau of Statistics, Labour and Prices Division, Employment Section, Man-Hours and Hourly Eamings, Catalogue 72-003, Selected Years.

Canada, Dominion Bureau of Statistics, Provincial Government Finance, Selected Years.

Canada, Dominion Bureau of Statistics, Popularion Estimates by Marital Status Age and Sex for Canada and Provinces, Selected Years.

Canada Dominion Bureau of Statistics, "National Income and Expenditure Accounis: Annual Estimates," Selected Years.

Canada, Department of Labour, Economics and Research Branch, Working Conditions in Canadian Indusiny, Selected Years.

Canadian Tax Foundation, Provincial Finances, Toronto: CTF, Selected Years.

Card, David. (1990). "Unexpected Inflation, Real Wages, and Employment Determination in Union Contracts," American Economic Review, 80:669-688,

Congressional Research Service (1988), Costs and Effects of Exrending Health Insurance Coverage, Washington, D.C.: CRS.

Government Accounting Office. (1991), Canadian Health Insurance: Lessons for the United States, Washington, D.C.

Gruber, Jonathan. (1992), "The Incidence of a Group-Specific Mandated Benefit: Evidence from Health insurance Benefits for Maternity". Nastonal Bureau of Economic Research Working Paper 44157.

Gruber, Jonathan and Alan Krueger. (1991). "The Incidence of Mandated Employer-Provided Insurance: Lessons from Worker's Compensation Insurance," Tax Policy and the Economy S, David Bradford, ed., Cambridge, MA: MIT Press.

Hanratty, Maria. (1992). "Canadian National Health Insurance and Infant Health," mimeo, Cornell University.

Health Insurance Association of America (1990), Source Book of Health Insurance Data, 
Washington,D.C.:HLAA.

Keeley, Michael. (1981), Labor Supply and Public Policy: A Critical Review (New York, NY: Academic Press).

LeClair, Maurice. (1973), "The Canadian Health Care System," in Spyros Andreopoulos, ed., National Health Insurance: Can We Learn from Canada?, New York: John Wiley

Madrian, Brigitte C. (1993), "Employment-Based Health Insurance and Job Mobility: Is There Evidence of Job-Lock?" NBER Working Paper H4476, September, 1993.

Moore, Michael, and W. Kip Viscusi (1990), Compensation Mechanisms for Job Risks, Princeton, NJ: Princeton University Press.

Newhouse, Joseph P. (1992), "Medical Care Costs: How Much Welfare Loss?," Journal of Economic Perspectives 6:3-21.

Rosen, Sherwin. (1986)., "The Theory of Equalizing Differences," in O. Ashenfelter and R. Layard, eds. Handbook of Labor Economics, Amsterdam: Elsevier Publishers.

Royal Commission on Health Services, (1965), Report of the Royal Commission on Health Services, Outawa: Queen's Printer.

Royal Commission on Taxation, (1966) Reporn of the Royal Commission on Taxarion. Volume 3. Ottawa: Queen's Printer, 1966

Shillington, Howard. (1972), The Road to Medicare in Canada. Toronto: Del Graphics.

Statistics Canada, Labour Division, Employment and Payrolls Section, Employment Earnings and Hours, Catalogue 72-002, Selected Years.

Statistics Canada (1988), Industrial Production: 1960-1987.

Summers, Lawrence, (1989) "Some Simple Economics of Mandated Benefits," American Economic Review,79:177-184.

Summers, Lawrence, Jonathan Gruber, and Rodrigo Vergara. (1993). "Taxation and the Structure of Labor Markets: The Case of Corporatism, Quarterly Journal of Economics, 108: $385-412$.

Taylor, Maicolm G. (1987), Health Insurance and Canadian Public Pollcy, Montreal: Mc-GillQueen's University Press.

U.S. Department of Commerce, Bureau of Census, Staristical Abstract of The United States, Washington DC: General Printing Office, 1992, Table 672.

Viscusi, W. Kip, and Michael J. Moore (1987), "Workers' Compensation: Wage Effects, Benefit Inadequacies, and the Value of Health Losses," Review of Economics and Statistics, vol LXIX, No. 2, 249-261. 
White, Halbert (1980), "A Heteroskedasticity-Consistent Covariance Matrix Estimator and a Direct Test for Heteroskedasticity," Econometrica, 48, 817-838. 
Table I:

Data of Entry Into Canadian National Health Insurance Program

\begin{tabular}{|l|l|c|c|}
\hline PROVINCE & DATE OF ENTRY & $\begin{array}{c}\% \\
\text { PREMIUM } \\
\text { IN FIRST } \\
\text { YEAR }\end{array}$ & $\begin{array}{c}\% \\
\text { PREMIUM } \\
\text { IN LAST } \\
\text { YEAR }\end{array}$ \\
\hline Newfoundland & April 1, 1969 & 0 & 0 \\
\hline Prince Edward Island & December 1, 1970 & 0 & 0 \\
\hline Nova Scotia & April 1, 1969 & 0 & 0 \\
\hline New Brunswick & January 1, 1971 & 0 & 0 \\
\hline Quebec & November 1, 1970 & 0 & 0 \\
\hline Ontario & October 1, 1969 & 97 & 47 \\
\hline Manitoba & April 1, 1969 & 36 & 0 \\
\hline Saskatchewan & July 1, 1968 & 22 & 0 \\
\hline Alberta & July 1, 1969 & 96 & 53 \\
\hline British Columbia & July 1, 1968 & 77 & 35 \\
\hline
\end{tabular}


Table II:

Means and Standard Deviations of Data Set

\begin{tabular}{|c|c|c|c|}
\hline Variable & Description of Variable & Mean & S. Dev. \\
\hline LEMP & Log total employment. & 9.947 & 1.309 \\
\hline LHOURS & $\begin{array}{l}\text { Log total hours per week. } \\
\text { Hours }=\text { (Hourly Employees * Avg Hrs of Hourly } \\
\text { Workers) }+ \text { (Nonhourly Workers * 37.5) }\end{array}$ & 13.774 & 1.301 \\
\hline $\begin{array}{l}\text { LAVGHOUR } \\
S\end{array}$ & $\begin{array}{l}\text { Log average hours per week. } \\
\text { Avg Hours = Hours / Total Employment. } \\
\text { Hours are computed as above. }\end{array}$ & 3.694 & 0.072 \\
\hline LWAGE & Log of average weekly earnings. & 4.673 & 0.407 \\
\hline NHI & $\begin{array}{l}=1 \text { if province has passed National Health Insurance, }=0 \\
\text { otherwise. }\end{array}$ & 0.465 & 0.499 \\
\hline NHI* א Tax & $\begin{array}{l}=\text { NHI * \% Provincial NHI Contributions financed by } \\
\text { General Revenues. }\end{array}$ & 0.333 & 0.419 \\
\hline HICOV & $\begin{array}{l}\text { Share of employes in firms which provide bealth } \\
\text { insurance to a majority ( }>50 \% \text { ) of their employees in } \\
1965 \text {. }\end{array}$ & 0.889 & 0.131 \\
\hline LGDP & Log of Provincial GDP (annual). & 8.314 & 1.379 \\
\hline LGDPI & Log of Industry GDP (monthy). & 9.714 & 0.753 \\
\hline DLGDP & Change in log Provincial GDP (year to year) & 0.103 & 0.053 \\
\hline DLGDPI & Change in log Industry GDP (month to month) & 0.047 & 0.063 \\
\hline
\end{tabular}

Sample consists of monthly data for 10 Canadian provinces for eight industries from 1961 to 1975 $(N=12,240)$, except for bours data, which only exists for 3 industries for 10 provinces for the years $1965-1975(\mathrm{~N}=3250)$. 
Table III:

The Impact of NHI on Employecut asd Wages

\begin{tabular}{|c|c|c|c|c|c|c|c|c|}
\hline \multicolumn{9}{|l|}{ Employtrent } \\
\hline NHI & $\begin{array}{r}0.0197 \\
(0.0061)\end{array}$ & $\begin{array}{r}0.0257 \\
(0.0063) \\
\end{array}$ & $\begin{array}{c}0.0216 \\
(0.0074)\end{array}$ & $\begin{array}{c}0.0248 \\
(0.0076)\end{array}$ & $\begin{array}{c}0.0138 \\
(0.0060)\end{array}$ & $\begin{array}{c}0.0131 \\
(0.0060)\end{array}$ & $\begin{array}{r}0.0171 \\
(0.0082) \\
\end{array}$ & $\begin{array}{r}0.0141 \\
(0.0083)\end{array}$ \\
\hline $\begin{array}{l}\text { NHI nex } \\
\text { year }\end{array}$ & & & $\begin{array}{r}0.0037 \\
(0.0065) \\
\end{array}$ & $\begin{array}{l}-0.0018 \\
(0.0065)\end{array}$ & & & $\begin{array}{r}0.0044 \\
(0.0067)\end{array}$ & $\begin{array}{r}0.0014 \\
(0.0067)\end{array}$ \\
\hline $\begin{array}{l}\text { Log Prov } \\
\text { GDP }\end{array}$ & & & & & & $\begin{array}{c}0.0829 \\
(0.0249) \\
\end{array}$ & & $\begin{array}{c}0.0820 \\
(0.0252)\end{array}$ \\
\hline $\begin{array}{l}\text { Log Ind } \\
\text { GDP }\end{array}$ & & & & & & $\begin{array}{r}0.2156 \\
(0.0289)\end{array}$ & & $\begin{array}{c}0.2155 \\
(0.0290)\end{array}$ \\
\hline $\begin{array}{l}\text { Chenge in bog } \\
\text { Prov GDP }\end{array}$ & & $\begin{array}{r}0.2378 \\
(0.0436)\end{array}$ & & $\begin{array}{c}0.2388 \\
(0.0436)\end{array}$ & & & & \\
\hline $\begin{array}{l}\text { Chenge in log } \\
\text { lad GDP }\end{array}$ & & $\begin{array}{r}0.3027 \\
(0.0480)\end{array}$ & & $\begin{array}{c}0.3024 \\
(0.0480)\end{array}$ & & & & \\
\hline $\begin{array}{l}\text { Provilnd } \\
\text { trend? }\end{array}$ & No & No & No & No & Yen & $Y=$ & Yea & Yes \\
\hline
\end{tabular}

\begin{tabular}{|c|c|c|c|c|c|c|c|c|}
\hline Wages & & & & & & & & \\
\hline NHI & $\begin{array}{c}0.0325 \\
(0.0022) \\
\end{array}$ & $\begin{array}{c}0.0022 \\
(0.0023)\end{array}$ & $\begin{array}{c}0.0221 \\
(0.0027)\end{array}$ & $\begin{array}{c}0.0418 \\
(0.0027) \\
\end{array}$ & $\begin{array}{c}0.0146 \\
(0.0024) \\
\end{array}$ & $\begin{array}{c}0.0141 \\
(0.0024)\end{array}$ & $\begin{array}{c}0.0167 \\
(0.0031)\end{array}$ & $\begin{array}{r}0.0156 \\
(0.0031)\end{array}$ \\
\hline NHI next year & & & $\begin{array}{c}0.0188 \\
(0.0026)\end{array}$ & $\begin{array}{c}0.0193 \\
(0.0026) \\
\end{array}$ & & & $\begin{array}{c}0.0029 \\
(0.0028)\end{array}$ & $\begin{array}{c}0.0020 \\
(0.0028)\end{array}$ \\
\hline Log Prov GDP & & & & & & $\begin{array}{c}0.0332 \\
(0.0108)\end{array}$ & & $\begin{array}{r}0.0319 \\
(0.0108) \\
\end{array}$ \\
\hline $\begin{array}{l}\log \text { Ind } \\
\text { GDP }\end{array}$ & & & & & & $\begin{array}{l}-0.0362 \\
(0.0124)\end{array}$ & & $\begin{array}{r}-0.0363 \\
(0.0124)\end{array}$ \\
\hline $\begin{array}{l}\text { Change in log } \\
\text { prov GDP }\end{array}$ & & $\begin{array}{l}-0.0134 \\
(0.0154)\end{array}$ & & $\begin{array}{c}-0.0241 \\
(0.0150)\end{array}$ & & & & \\
\hline $\begin{array}{l}\text { Chenge in bo } \\
\text { ind GDP }\end{array}$ & & $\begin{array}{r}-0.0136 \\
(0.0162)\end{array}$ & & $\begin{array}{l}-0.0144 \\
(0.0162)\end{array}$ & & & & \\
\hline Provflad trend? & No & No & No & No & Yea & You & Yen & Yea \\
\hline
\end{tabular}

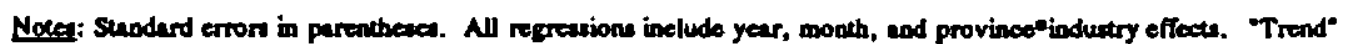
regreasiona ale include trend, and trend interncted with provincetinductry effects. Number of observations is 11,424: Depeadent variables are all is loga. 
Table IV:

Impact of NEII on Emplorment, Hours and Average Hours/Week

\begin{tabular}{|c|c|c|c|c|c|c|}
\hline & Total Hours & Totel Hours & Employmeat & Employment & Av. Hours & Av. Hours \\
\hline NHI & $\begin{array}{c}0.0601 \\
(0.0120)\end{array}$ & $\begin{array}{c}0.0371 \\
(0.0118)\end{array}$ & $\begin{array}{c}0.0607 \\
(0.0106)\end{array}$ & $\begin{array}{c}0.0346 \\
(0.0097)\end{array}$ & $\begin{array}{c}-0.0006 \\
(0.0034)\end{array}$ & $\begin{array}{c}0.0025 \\
(0.0042)\end{array}$ \\
\hline $\begin{array}{c}\text { Change in Log } \\
\text { Province GDP }\end{array}$ & $\begin{array}{c}0.2367 \\
(0.0910)\end{array}$ & & $\begin{array}{c}0.2194 \\
(0.0809)\end{array}$ & & $\begin{array}{c}0.0173 \\
(0.0236)\end{array}$ & \\
\hline $\begin{array}{c}\text { Cheoge in Log } \\
\text { lodustry GDP }\end{array}$ & $\begin{array}{c}0.0662 \\
(0.0408)\end{array}$ & & $\begin{array}{c}0.0453 \\
(0.0353)\end{array}$ & & $\begin{array}{c}0.0208 \\
(0.0123)\end{array}$ & \\
\hline $\begin{array}{c}\text { Log Province } \\
\text { GDP }\end{array}$ & & $\begin{array}{c}0.0611 \\
(0.0575)\end{array}$ & & $\begin{array}{c}0.0800 \\
(0.0471)\end{array}$ & & $\begin{array}{c}0.0189 \\
(0.0193)\end{array}$ \\
\hline $\begin{array}{c}\text { Log Industry } \\
\text { GDP }\end{array}$ & & $\begin{array}{c}0.4480 \\
(0.0424)\end{array}$ & & $\begin{array}{c}0.3865 \\
(0.0354)\end{array}$ & & $\begin{array}{c}0.0615 \\
(0.0135)\end{array}$ \\
\hline $\begin{array}{c}\text { Prov/lod } \\
\text { Tread? }\end{array}$ & No & Yes & No & Yes & No & Yes \\
\hline
\end{tabular}

Standurd errors are reported in parentheses. Represeots subset of the sample which has information on hours; this includes 3 industries for 10 provinces for the years 1965-1975. $N=3250$. Regressions also include year, month, and province"industry effects. "Tread" regressions also include tread and tread"province"industry effects. Depeodeat variables are all in logs. 
Table V: Dyamica of NHI Implemeatation

\begin{tabular}{|c|c|c|c|c|}
\hline & Employment & Empioyment & Wagea & Wages \\
\hline NHI in 4 quartere & $\begin{array}{c}-0.0192 \\
(0.0103) \\
\end{array}$ & $\begin{array}{r}-0.0098 \\
(0.0098)\end{array}$ & $\begin{array}{r}0.0164 \\
(0.0047) \\
\end{array}$ & $\begin{array}{r}0.0057 \\
(0.0048) \\
\end{array}$ \\
\hline NHI in 3 quarters & $\begin{array}{c}0.0106 \\
(0.0109) \\
\end{array}$ & $\begin{array}{l}-0.0031 \\
(0.0102)\end{array}$ & $\begin{array}{r}0.0137 \\
(0.0040) \\
\end{array}$ & $\begin{array}{r}0.0012 \\
(0.0041) \\
\end{array}$ \\
\hline NHI in 2 quarters & $\begin{array}{c}0.0025 \\
(0.0093) \\
\end{array}$ & $\begin{array}{r}0.0135 \\
(0.0096) \\
\end{array}$ & $\begin{array}{c}0.0171 \\
(0.0044) \\
\end{array}$ & $\begin{array}{r}-0.0009 \\
(0.0043) \\
\end{array}$ \\
\hline NHl is 1 querter & $\begin{array}{c}0.0070 \\
(0.0098) \\
\end{array}$ & $\begin{array}{r}0.0159 \\
(0.0097) \\
\end{array}$ & $\begin{array}{r}0.0290 \\
(0.0040) \\
\end{array}$ & $\begin{array}{r}0.0093 \\
(0.0039) \\
\end{array}$ \\
\hline NHI 1 quarter ago & $\begin{array}{l}-0.0091 \\
(0.0130)\end{array}$ & $\begin{array}{r}-0.0034 \\
(0.0110) \\
\end{array}$ & $\begin{array}{r}0.0235 \\
(0.0046) \\
\end{array}$ & $\begin{array}{r}0.0061 \\
(0.0046) \\
\end{array}$ \\
\hline NHI 2 quarter ego & $\begin{array}{r}0.0067 \\
(0.0133) \\
\end{array}$ & $\begin{array}{c}0.0108 \\
(0.0116) \\
\end{array}$ & $\begin{array}{r}0.0264 \\
(0.0043) \\
\end{array}$ & $\begin{array}{r}0.0079 \\
(0.0041) \\
\end{array}$ \\
\hline NHI 3 quarters 180 & $\begin{array}{c}0.0247 \\
(0.0102) \\
\end{array}$ & $\begin{array}{c}0.0281 \\
(0.0106) \\
\end{array}$ & $\begin{array}{c}0.0248 \\
(0.0044) \\
\end{array}$ & $\begin{array}{r}0.0018 \\
(0.0045) \\
\end{array}$ \\
\hline NHI \& quarters \& 80 & $\begin{array}{c}0.0209 \\
(0.0104) \\
\end{array}$ & $\begin{array}{c}0.0251 \\
(0.0102) \\
\end{array}$ & $\begin{array}{r}0.0484 \\
(0.0043) \\
\end{array}$ & $\begin{array}{r}0.0234 \\
(0.0408) \\
\end{array}$ \\
\hline NHI 5 quirers ago & $\begin{array}{r}0.0070 \\
(0.0134) \\
\end{array}$ & $\begin{array}{r}0.0105 \\
(0.0122) \\
\end{array}$ & $\begin{array}{r}0.0540 \\
(0.0043) \\
\end{array}$ & $\begin{array}{r}0.0280 \\
(0.0043) \\
\end{array}$ \\
\hline NHI 6 quaren ago & $\begin{array}{c}0.0172 \\
(0.0141) \\
\end{array}$ & $\begin{array}{c}0.0205 \\
(0.0129) \\
\end{array}$ & $\begin{array}{r}0.0498 \\
(0.0043) \\
\end{array}$ & $\begin{array}{r}0.0234 \\
(0.0042) \\
\end{array}$ \\
\hline NHI 7 quartera ago & $\begin{array}{c}0.0435 \\
(0.0115) \\
\end{array}$ & $\begin{array}{c}0.0073 \\
(0.0114) \\
\end{array}$ & $\begin{array}{r}0.0500 \\
(0.0043) \\
\end{array}$ & $\begin{array}{r}0.0240 \\
(0.0042) \\
\end{array}$ \\
\hline NHI 8 quariers 480 & $\begin{array}{c}0.0417 \\
(0.0120) \\
\end{array}$ & $\begin{array}{c}0.0275 \\
(0.0114) \\
\end{array}$ & $\begin{array}{r}0.0519 \\
(0.0057) \\
\end{array}$ & $\begin{array}{c}0.0261 \\
(0.0054) \\
\end{array}$ \\
\hline $\begin{array}{l}\text { NHl more than } \\
8 \text { quarters ego }\end{array}$ & $\begin{array}{c}0.0485 \\
(0.0104) \\
\end{array}$ & $\begin{array}{c}0.0016 \\
(0.0104) \\
\end{array}$ & $\begin{array}{c}0.0543 \\
(0.0033) \\
\end{array}$ & $\begin{array}{r}0.0294 \\
(0.0036) \\
\end{array}$ \\
\hline $\begin{array}{l}\text { Cherge in Log } \\
\text { Province COP }\end{array}$ & $\begin{array}{r}0.2497 \\
(0.0454) \\
\end{array}$ & & $\begin{array}{l}-0.0190 \\
(0.0155)\end{array}$ & $\begin{array}{r}0.0419 \\
(0.0110) \\
\end{array}$ \\
\hline $\begin{array}{l}\text { Chenge in Log } \\
\text { Induetry GDP }\end{array}$ & $\begin{array}{c}0.3006 \\
(0.0479) \\
\end{array}$ & & $\begin{array}{r}-0.0160 \\
(0.0162) \\
\end{array}$ & $\begin{array}{r}-0.0072 \\
(0.0124) \\
\end{array}$ \\
\hline Log Province GDP & & $\begin{array}{c}0.0928 \\
(0.0258) \\
\end{array}$ & & $m m$ \\
\hline Log Industry GDP & $\cdots$ & $\begin{array}{c}0.2150 \\
(0.0289) \\
\end{array}$ & . & $m m$ \\
\hline Prov/lod Tread ? & No & Yea & No & Ye \\
\hline
\end{tabular}

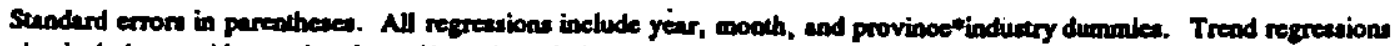
steo include monthly trend and trend"provinoe"induatry controls. All repreasions have 11,424 observation. Dependene variables are all in loga. 
31

Table VI: The Impact of NHI on Employment and Wages

by Financine Method \& Insurance Coverage

\begin{tabular}{|c|c|c|c|c|}
\hline \multicolumn{5}{|l|}{ Employmeot } \\
\hline NHI & $\begin{array}{c}0.7405 \\
(0.0202)\end{array}$ & $\begin{array}{c}0.7215 \\
(0.0201)\end{array}$ & $\begin{array}{c}0.0049 \\
(0.0230)\end{array}$ & $\begin{array}{c}0.0177 \\
(0.0232)\end{array}$ \\
\hline $\mathrm{NHI} * \$ \mathrm{HICOV}$ & $\begin{array}{r}-0.6788 \\
(0.0199)\end{array}$ & $\begin{array}{r}-0.6568 \\
(0.0198)\end{array}$ & $\begin{array}{c}0.0271 \\
(0.0239)\end{array}$ & $\begin{array}{r}0.0200 \\
(0.0240)\end{array}$ \\
\hline NHI * $\%$ Tax & $\begin{array}{c}-0.2013 \\
(0.0061)\end{array}$ & $\begin{array}{r}-0.1968 \\
(0.0061)\end{array}$ & $\begin{array}{l}-0.0419 \\
(0.0057)\end{array}$ & $\begin{array}{c}-0.0547 \\
(0.0060)\end{array}$ \\
\hline Log Province GDP & . & & & $\begin{array}{r}0.1224 \\
(0.0161)\end{array}$ \\
\hline $\begin{array}{l}\text { Log Industry } \\
\text { GDP }\end{array}$ & & & & $\begin{array}{r}0.0726 \\
(0.0132)\end{array}$ \\
\hline $\begin{array}{l}\text { Crenge is log } \\
\text { province GDP }\end{array}$ & & $\begin{array}{c}0.1231 \\
(0.0325)\end{array}$ & & \\
\hline $\begin{array}{l}\text { Chenge in log } \\
\text { industry GDP }\end{array}$ & & $\begin{array}{c}0.2865 \\
(0.0328)\end{array}$ & & \\
\hline Provilnd tread? & No & No & 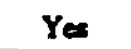 & Yes \\
\hline
\end{tabular}

\begin{tabular}{|c|c|c|c|c|}
\hline Wages & & & & \\
\hline NHI & $\begin{array}{r}-0.0059 \\
(0.0079)\end{array}$ & $\begin{array}{l}-0.0022 \\
(0.0079)\end{array}$ & $\begin{array}{c}0.1075 \\
(0.0128)\end{array}$ & $\begin{array}{r}0.1076 \\
(0.0129)\end{array}$ \\
\hline NHI * HICOV & $\begin{array}{r}0.0327 \\
(0.0080)\end{array}$ & $\begin{array}{r}0.0286 \\
(0.0079)\end{array}$ & $\begin{array}{r}-0.0914 \\
(0.0133)\end{array}$ & $\begin{array}{r}-0.0873 \\
(0.0133)\end{array}$ \\
\hline NHI * $\%$ Tax & $\begin{array}{c}0.0038 \\
(0.0025)\end{array}$ & $\begin{array}{r}0.0034 \\
(0.0025)\end{array}$ & $\begin{array}{l}-0.0322 \\
(0.0032)\end{array}$ & $\begin{array}{r}-0.0403 \\
(0.0033)\end{array}$ \\
\hline Log Provisce GDP & & & & $\begin{array}{r}0.0837 \\
(0.0097)\end{array}$ \\
\hline $\begin{array}{l}\text { Log Inchustry } \\
\text { GDP }\end{array}$ & & & & $\begin{array}{r}-0.0545 \\
(0.0081)\end{array}$ \\
\hline $\begin{array}{l}\text { Chenge is los } \\
\text { province GDP }\end{array}$ & & $\begin{array}{c}-0.0013 \\
(0.0131)\end{array}$ & & \\
\hline $\begin{array}{l}\text { Chenge in log } \\
\text { industry GDP }\end{array}$ & & $\begin{array}{r}-0.0482 \\
(0.0112)\end{array}$ & & \\
\hline Prov/lnd tread? & No & No & Yes & Yea \\
\hline
\end{tabular}

standard erron in parentbeses. All regresion include year dummies, month dummies, end province industry offects. "Tread" regreasions include tread, and trood inieracted with provincetinductry effects. Semple axcludes constnuction apd forestry industriea. $N=9072$. Dependene variables aro in loga. 